\title{
AZ ÉKSZÍJTÁRCSA ÁTMÉRőK ÉS AZ ÉKSZÍJAK MELEGEDÉSI VISZONYAINAK KAPCSOLATA
}

\section{RELATIONSHIP BETWEEN THE PULLEY DIAMETER AND V-BELT TEMPERATURE CONDITIONS}

\author{
Gárdonyi Péter ${ }^{1}$, Kátai László ${ }^{2}$, Szabó István ${ }^{3}$ \\ ${ }^{I}$ Szent István Egyetem, Gépészmérnöki Kar, Gépszerkezettan Tanszék, \\ Cím: Magyarország, 2100 Gödöllö, Páter Károly u. 1. Telefon / Fax: +36-28- \\ 522080/1486,gardonyi.peter@hallgato.szie.hu \\ ${ }^{2}$ Szent István Egyetem, Gépészmérnöki Kar, Gépszerkezettan Tanszék, \\ Magyarország, 2100 Gödöllö, Páter Károlyu. 1., katai.laszlo@gek.szie.hu \\ ${ }^{3}$ Szent István Egyetem, Gépészmérnöki Kar, Gépszerkezettan Tanszék, \\ Magyarország, 2100 Gödöllö, Páter Károlyu.1., szabo.istvan@gek.szie.hu
}

\begin{abstract}
Main objective of this paper is analyzing the temperature conditions of V-belt by infrared thermal camera depending on various pulley diameters. A speed ratio needed for a certain V-belt drive can be solved with wide spectra of pulley diameters. Defining the optimal pulley diameter is a complex procedure during drive design because the minimal diameter is specified by standards and the maximum diameter is limited by the allowable belt speed. In this study an experimental method was developed to define the V-belt temperature increase in function of pulley diameter in order to select the optimal pulley size.
\end{abstract}

Keywords: V-belt, infrared thermal analysis, temperature conditions.

\section{Összefoglalás}

A szíjhajtások tervezésénél általában a hajtott gépegység nyomatékigényét és a fordulatszámát vesszük alapul, majd áttételen keresztül összhangba hozzuk a meghajtó egységgel. Az előírt fordulatszámértékhez tartozó áttétel több tárcsaátmérő kombinációjával is megoldható, így a tervezőre hárul az a feladat, hogy különböző szempontokat figyelembe véve határozza meg az optimálisnak tekinthető szíjtárcsa átmérőket. Az adott szíjtípushoz alkalmazható legkisebb tárcsaátmérőt szabvány írja elő, a legnagyobb átmérő értékét pedig a megengedhető maximális szíjsebesség korlátozza. A tanulmány célja, olyan kísérleti módszer kidolgozása, amely a tárcsaátmérő függvényében meghatározza az ékszíj melegedését, ezzel segítséget nyújtva az optimálisnak tekinthető átmérő kiválasztásához.

Kulcsszavak: ékszijj, infravörös termográfia, ékszijtárcsa átmérö, szijhőmérséklet.

\section{Bevezetés, célkitűzés}

A szíjhajtások teljesítmény-átvitele során a szíj melegedése alapvetően két hatás eredménye. Az érintkező felületek makroszkopikus súrlódása következtében fejlödő hő, és a szíj ismétlődő igény-bevétele következtében fellépő hiszterézis veszteség hővé alakuló hányada. [2] Az ékszíjhajtás, mint minden gépszerkezet, bizonyos hatásfokkal üzemel, amely a hasznos és a bevezetett teljesítmény hányadosa. Ezeknek a különbsége adja a teljesítményveszteséget, amelynek nagy része hővé alakul. Ha az 
ékszíj állandósult hőmérsékletét vizsgáljuk, mint veszteségintenzitást, abból következtetni lehet a szíjhajtás hatásfokára. A magasabb szíjhömérséklet a molekulaláncok degradálásához, a gumi öregedéséhez vezet, ezáltal jelentősen befolyásolja az ékszíj élettartamát. Célunk egy olyan kísérleti módszer kidolgozása, amellyel a szíjhajtás hőmérséklet-emelkedése üzemi körülmények között vizsgálható.

\section{Az ékszíj melegedése a tárcsa- átmérő függvényében}

A Tanszéken folyó kutatások kiemelt területe a rugalmas hajtások vizsgálata. Kátai kísérleti úton meghatározta a tárcsaátmérö szíjhőmérséklet-emelkedésre gyakorolt hatását. A vizsgálatait egy saját tervezésü próbapadon végezte, ahol egy ismételt hajlítgatásnak kitett ékszíjdarab hőmérsékletét mérte tíz perces intervallumban. A hőmérséklet-emelkedés értékét a kiindulási és az utolsó $30 \mathrm{~s}$ alatt mért értékek átlagának különbségeként határozta meg.

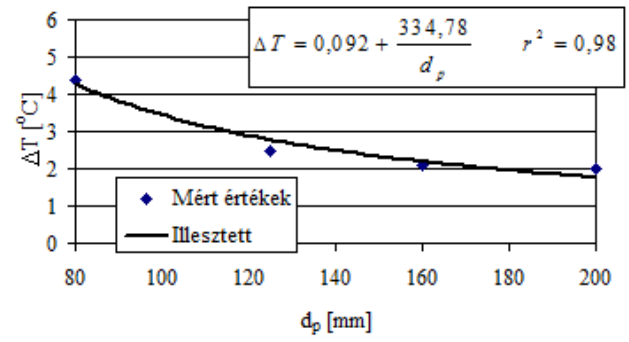

1. ábra. $A z \Delta T=a+b / d_{p}$ függvény alakban történö illesztés eredménye $\left(F_{H}=300 \mathrm{~N}, f=2901 / \mathrm{min}\right)$ [3]

Az 1. ábra a mérési pontokat és a függvényillesztést szemlélteti adott előfeszítés és szíjfrekvencia beállítások mellett a tárcsaátmérő függvényében. Kátai a matematikai modellt, a szijban keletkező hajlító igénybevétel $\sigma_{\text {hajl }}=E_{\text {hajl }} \cdot s / d$ elméleti összefüggésének megfelelöen $\Delta T=a / d_{p}$ és $\Delta T=c / d_{p}{ }^{2}$ függvény formájában kereste. A 2. ábrán a különböző matematikai modellek illesztéseinek korrelációs együtthatói láthatók.

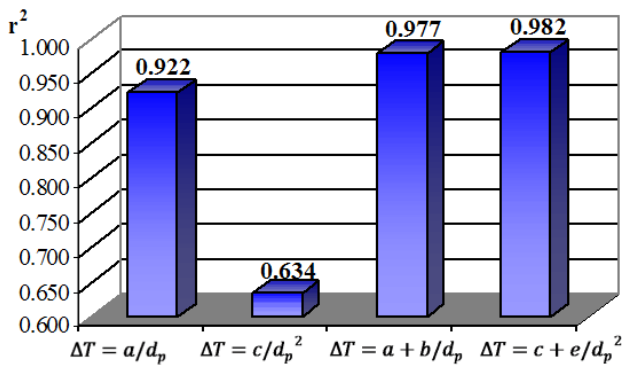

2. ábra. A matematikai modellek összehasonlitása [3]

\section{A vizsgálati berendezés és esz- közei}

A méréseinket a Tanszéken fejlesztett univerzális tesztpadon végeztük. A 3. ábrán látható a kísérleti elrendezés, ahol nagy felbontású $(640$ x 480) infrakamerával $1 \mathrm{~Hz}$ frekvenciával 20 perces időtartamban készítettünk felvételeket.

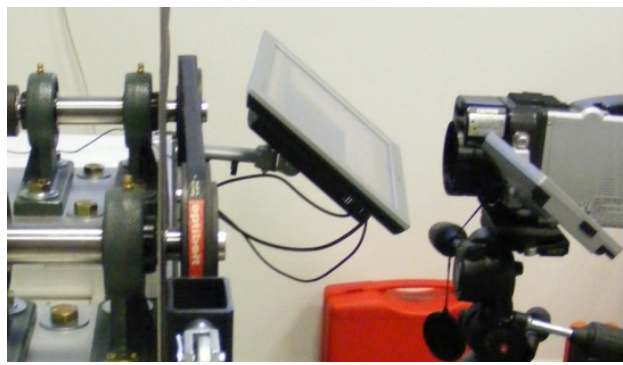

\section{3. ábra. A kisérleti elrendezés}

Kísérleteink során az ékszíj tárcsahoronnyal érintkező oldalfelületeit vizsgáltuk, amelyek a hajtás müködéséről több információt tartalmaztak. Az ékszíj aktív felületéről készült hökamerás felvételből képfeldolgozás után nyertünk hőmérsékleti adatokat. A 4. ábrán látható, kijelölt területek átlaghőmérsékletét használtuk fel a kiértékeléshez. 
A méréseket SPA profilú ékszíjjal $\left(L_{i}=1207 \mathrm{~mm}\right), \quad 1: 1$ áttétellel és $d_{p}=90,112,132,150,180 \mathrm{~mm}$ névleges átmérőjü tárcsákkal végeztük $f=20 \mathrm{~s}^{-1}$ szíjhajlítgatás mellett. A hajtást terhelés nélkül vizsgáltuk, így a hö fejlödésben csak az ékszíjhajtás geometriai viszonyai, valamint az anyagjellemzők játszottak szerepet.

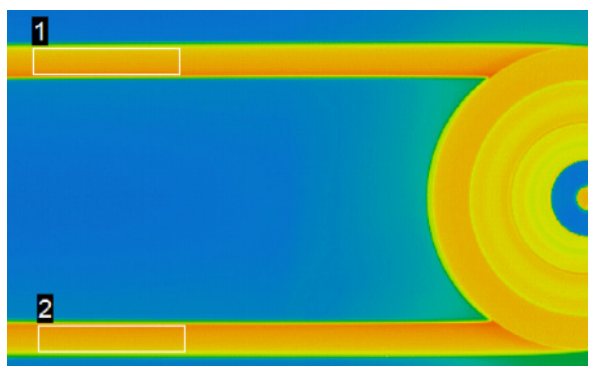

4. ábra. A hökamerás felvétel, és kiértékelése

\section{A vizsgálat értékelése, eredmé- nyek}

Az ékszij melegedését a BauleMitscherlich-féle telítődési függvény írja le (5. ábra), amelyben a mért paraméterek egy csökkenő gradiens mentén változnak a telítettségi maximum felé haladva. [4]

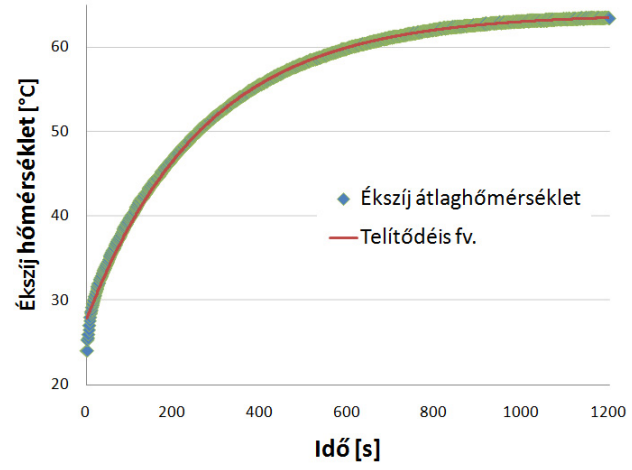

5. ábra. A mérési adatok és a telitödési függvén

A telítődési függvény általános összefüggése

$$
Y=A \cdot\left(1-e^{z+c \cdot X}\right) .
$$

Az egyszerüsítet forma

$$
Y=A \cdot(1-m) \text {, }
$$

ahol az $A$ a telítődési függvény felső határa. Az $m=e^{z+c \cdot X}$ a relatív telítetlenség, azaz az $Y$ érték távolság az $A$ maximumtól, az $A$ maximumra vonatkoztatva[4]:

$$
m=1-\frac{Y}{A}=\frac{A-Y}{A} \text {. }
$$

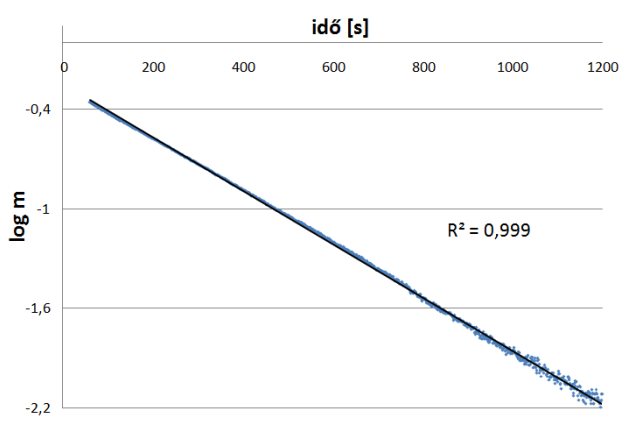

6. ábra. logm lineáris regressziója

A kísérleti adatok telítődési függvényre való illeszkedését a $\log m$ lineáris regreszsziója igazolta (6. ábra) [4]. A mérésekböl meghatározott függvény konstans értékeit az 1. táblázat foglalja magába a tárcsaátmérőkre vonatkozóan. A függvényparaméterek közül az $A$ az ékszíj állandósult hőmérsékletét, $c$ a melegedés sebességét és a $z$ pedig a mérés kezdetén a szij hőmérsékletét adja

\begin{tabular}{|c|c|c|c|}
\hline 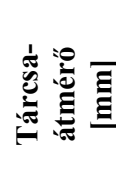 & 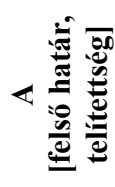 & 0 总总总 & 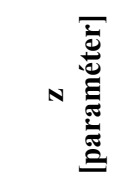 \\
\hline 90 & 63,9 & $-0,00370$ & $-0,56879$ \\
\hline 112 & 51,8 & $-0,00264$ & $-0,81684$ \\
\hline 132 & 43,7 & $-0,00201$ & $-1,06473$ \\
\hline 150 & 38,9 & $-0,00229$ & $-1,26919$ \\
\hline 180 & 33,0 & $-0,00308$ & $-1,84975$ \\
\hline
\end{tabular}
meg.

1. táblázat. Telitödési függvény konstans értékei 
$\mathrm{Az}$ ékszíj hőmérsékletének változása, azaz a kiindulási és a telítődési hőmérséklet különbség segítségével vizsgálható a szíjtárcsa átmérők hatása az azonos körülmények között üzemelő szíjhajtások esetén. A 7. ábrán látható az ékszíj hőmérsékletemelkedése a tárcsaátmérők függvényében, valamint a mérési pontokra illesztett görbék.

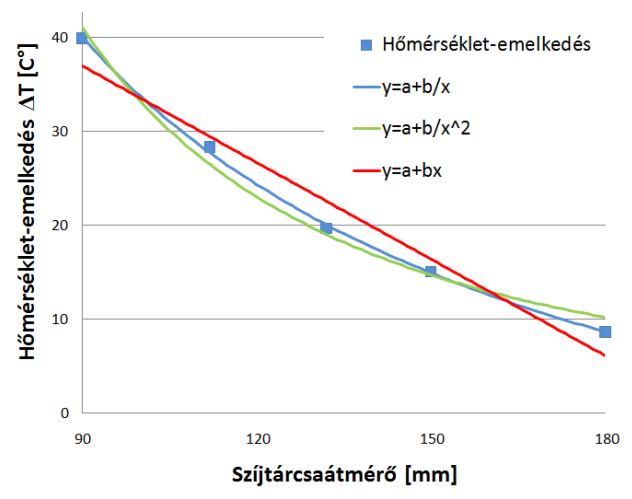

7. ábra. A hömérsékletek-emelkedés a tárcsaátmérö függvényében

Kátai által meghatározott, két legpontosabb függvény formájában, valamint egyenes illesztéssel kerestük az ékszíj melegedését leíró görbéket a tárcsaátmérő függvényében. Az illesztések eredményének megfelelöen a $y=a+b / x$ matematikai modell írja le a legpontosabban a tárcsaátmérō és az ékszíj hőmérséklet-emelkedés kapcsolatát.

2. táblázat. A tárcsaátmérö és az ékszij hömérséklet-emelkedését leiró modell konstans értékei, valamint a regressziós együtthatók

\begin{tabular}{|c|c|c|c|}
\hline függvény & $\mathrm{a}$ & $\mathrm{b}$ & $\boldsymbol{r}^{\mathbf{2}}$ \\
\hline $\boldsymbol{y}=\boldsymbol{a}+\boldsymbol{b} / \boldsymbol{x}$ & $-22,705$ & 5651,13 & 0,9991 \\
\hline $\boldsymbol{y}=\boldsymbol{a}+\boldsymbol{b} / \boldsymbol{x}^{\mathbf{2}}$ & $-0,0478$ & 332976,6 & 0,9871 \\
\hline $\boldsymbol{y}=\boldsymbol{a}+\boldsymbol{b} \cdot \boldsymbol{x}$ & 67,897 & $-0,34319$ & 0,9554 \\
\hline
\end{tabular}

\section{5. Összefoglalás}

A kidolgozott kísérleti módszert alkalmazva hasonló eredményt kaptunk a tárcsaátmérő és az ékszíj hőmérséklet-emelkedés kapcsolatára, mint a Kátai féle szíjhajlítgatás vizsgálata. A kísérleti sorozattal tehát kiválthatók az ékszíjmelegedésével foglalkozó hajlítgatás-vizsgálatok.

A kísérlet nagy elönye, hogy a szíjhajtást valós üzemi körülmények között lehet vizsgálni, és a további szíjmelegedés kísérletekbe más faktorok is bevonhatók (pl.: ékszíj előfeszítése, szíjcsúszás, átvitt nyomaték, stb.). A módszer másik előnye, hogy a mérés során nem kell elérni a szíjhőmérséklet állandósult állapotát, mivel a kiértékelésnél a melegedést leíró függvényből meghatározott telítődési hőmérséklettel számolunk.

$\mathrm{Az}$ ékszíjmelegedés vizsgálataink további célja, hogy a szíjhajtások méretezését segítve olyan tervezési tényezőket, összefüggéseket határozzunk meg, amelyekkel a szíjhajtások kedvező hatásfokkal és élettartammal hozhatók létre.

\section{Szakirodalmi hivatkozások}

[1] Gárdonyi P., Kátai L., Szabó I.: A hajtás beállitási hiba és az ékszijak melegedési viszonyainak kapcsolata, GÉP, Miskolc, 2014, 26-29.

[2] Kátai L.: Ékszijhajtások hajlitás hatására fellépö höterhelésének vizsgálata, Mezőgazdasági Technika, 2001. 2-3.

[3] Kátai L.: Terménybetakaritó gépeken alkalmazott ékszijak élettartam növelésének egyes kérdései, Doktori értekezés, Gödöllö, 2001, 89-93.

[4] Sváb J.: Biometriai módszerek a kutatásban, Mezőgazdasági Kiadó, Budapest, 1973, 390-397. 